\title{
THE DIESEL AND THE VEGETABLE OIL PROPERTIES ASSESSMENT IN TERMS OF PUMPING CAPABILITY AND COOPERATION WITH INTERNAL COMBUSTION ENGINE FUELLING SYSTEM
}

\author{
Dariusz SZPICA* ,Jarosław CZABAN*, Piotr BANASZUK*", Emil WERESA*
}

\author{
${ }^{*}$ Faculty of Mechanical Engineering, Department of Mechanical Engineering, \\ Bialystok University of Technology, ul. Wiejska 45C, 15-351 Bialystok, Poland \\ ${ }^{* *}$ Faculty of Civil and Environmental Engineering, Department of Environmental Protection and Management, \\ Bialystok University of Technology, ul. Wiejska 45E, 15-351 Bialystok, Poland
}

\section{d.szpica@pb.edu.pl, i.czaban@pb.edu.pl, p.banaszuk@pb.edu.pl, e.weresa@pb.edu.pl}

\begin{abstract}
In the paper, the results of preliminary diesel and vegetable oil research were shown, the subject of which were directly intended to be the fuel for powering compression ignition engines. In the times of climate protection and more strict standards concerning combustion gas emissions, the fuel production and transportation process became an important aspect. Decentralization of this process and enabling fuel obtaining directly from cultivation (oleaginous plants) let limit the global $\mathrm{CO}_{2}$ emission. This is why the preliminary assessment of two fuel sorts properties was attempted, on one side, the basic one, which is the diesel, on the other side - vegetable oil. Prior to subjecting the compression ignition engine to the process of adaptation to vegetable fuelling, the properties of the fuel responsible for pumping should be assessed (mainly viscosity) and friction nodes cooperation (lubricity). The first of researched parameters is the base to elaborating the system of engine controlling algorithm or the range of changes in construction of powering system. The second one is the wear issue - object fitness and repairing overhauls.
\end{abstract}

Key words: Internal Combustion Engine, Alternative Fuels, Rheological Properties

\section{INTRODUCTION}

The realization of ambitious European Union plans for climate protection will be demanding the resetting the energy production system in Europe to nearly non-emission one, stable in terms of supply and not weakening the European economy competitiveness. Lowering the emission in transport section must reach the level of $60 \%$ before 2050 comparing to 1990 and around $20 \%$ before 2030 comparing to 2008. Last years, the emission of GHG (greenhouse gases) significantly decreases, due to the growing oil prices, bigger engines efficiency and slower society's mobility increase. Such tendency will probably maintain till 2020, but in following years, there will be a quick resetting of exisisting transport system required. The significant element of activities will be a research in new technology in driving systems and alternative fuels, including biofuels (A policy..., 2014).

It is known, that the bio-fuels production on the rural areas would not cover the global need and that is why they could not replace fossil fuels (HLPE, 2013). Applying them as components to the transport fuels is a transient solution, potentially loaded with undesirable side effects for environment. The bio-fuels application is advised in such mobility sections, where nowadays the realistic and promising alternative solutions cannot be obtained: including agricultural activity, forestry and flight transport (Opinion..., 2013).

The agro-fuels' research concerns two main issues: fuel production, especially the ways of lowering undesirable components containment and adaptation of the engines to qualitative new fuel usage, including improving fuel serving and combustion optimization, so that the maintaining the engine power and gas and dust pollution limiting were possible, according to valid standards (Commission Directive 2010/26/UE, Embeger et al., 2012).

Powering the compression ignition engine with FAME (Fatty
Acid Methyl Esters) and raw oil from various seeds, which have lower energetic value than diesel oil, is connected to increase of time specific fuel consumption, at almost unchanged general efficiency value, but nitrous oxides (NOx) and solid particles emission is bigger (Cisek and Mruk, 2012; Dzieniszewski and Piekarski, 2006; Pasyniuk and Golimowski, 2011; Wasilewski, 2006; Tesfa, 2014; Durbin, 2000; Kaplan et al., 2006; Karavalakis et al., 2009; Nabi et al., 2006; Cranacki, 2007; Lin et al., 2009; Raheman and Phadatare, 2004; Xue et al., 2011; Amaranath et al., 2012).

The combustion course comparison implies, that rapeseed oil ester combustion is energetically comparable with diesel, in spite of lower heating value $(35-37) \mathrm{MJ} / \mathrm{kg}$ in lieu of $42 \mathrm{MJ} / \mathrm{kg}$, within constant combustion chamber volume and common-rail dualphase injection (Bocheński et al., 2005). The problem is with large value of bio-fuel viscosity (Tab. 1).

Tab. 1. The viscosity values of the most popular vegetable oils used as diesel engine fuels

\begin{tabular}{|l|r|c|c|c|c|}
\hline \multirow{2}{*}{ Autors } & \multicolumn{5}{|c|}{ Fuel } \\
\cline { 2 - 6 } & rapeseed & soybean & sunflower & corn & diesel \\
\hline \multicolumn{5}{|c|}{ dynamic viscosity, mPa.s } \\
\hline (Wcisło,2008) & $\begin{array}{r}42\left(-10^{\circ} \mathrm{C}\right) \\
13\left(20^{\circ} \mathrm{C}\right)\end{array}$ & $\begin{array}{r}36\left(-10^{\circ} \mathrm{C}\right) \\
13\left(20^{\circ} \mathrm{C}\right)\end{array}$ & & $\begin{array}{r}10.3\left(-10^{\circ} \mathrm{C}\right) \\
8.4\left(20^{\circ} \mathrm{C}\right)\end{array}$ \\
\hline \multicolumn{6}{|c|}{ kinematic viscosity, $\mathrm{mm}^{2} \cdot \mathrm{s}^{-1}$} \\
\hline $\begin{array}{l}\text { (Bocheński, } \\
\text { Bocheńska,2005) }\end{array}$ & $4.72\left(40^{\circ} \mathrm{C}\right)$ & & & $1.8\left(40^{\circ} \mathrm{C}\right)$ \\
\hline (Laska et al.,2013) $36.46\left(15^{\circ} \mathrm{C}\right)$ & & $41.08\left(15^{\circ} \mathrm{C}\right)$ & $33.81\left(15^{\circ} \mathrm{C}\right)$ & \\
\hline
\end{tabular}

The $15 \%$ rapeseed oil ester addition to diesel fuel causes insignificant, by $1.9 \mathrm{~mm}^{2} \cdot \mathrm{s}^{-1}$ in $40^{\circ} \mathrm{C}$ temperature fuel viscosity increase, while $30 \%$ addition increases the viscosity by $2.8 \mathrm{~mm}^{2} \cdot \mathrm{s}^{-1}$. Such viscosity increase insignificantly worsens the 
fuel spray, but does not influence the wear properties in essential way, however $30 \%$ of rapeseed oil esther increases filter blocking temperature from $-34{ }^{\circ} \mathrm{C}$ to $-17{ }^{\circ} \mathrm{C}$ (Bocheński and Bocheńska, 2005).

Tests conducted on agricultural tractors showed, that without big obstacles, the engine can wark on pure vegetable oil during period with temperatures over $0^{\circ} \mathrm{C}$, in lower temperatures, either the engine heating or diesel oil addition is required (2ndWegOil, Money et al., 2001, Pasyniuk and Golimowski, 2011). As a fuel, besides the fresh vegetable oil, also the cooking oil (exploited) is used. The supplement of 20 and $50 \%$ of the filtered cooking oil, is optimal, in order to exhaust gas emission (Lin et al., 2007). Powering the Fiat Doblo 1.9 DS with used cooking oil caused very low loss of the tractive force on wheels $(3.35 \%)$, and as well, the the lower power $(2.03 \%)$ relative to the vehicle powered with diesel fuel. In acceleration tests from 40 to $100 \mathrm{~km} / \mathrm{h}$ and from 60 to $100 \mathrm{~km} / \mathrm{h}$ the times lengthened consequently by $7.32 \%$ and $8.78 \%$.

There were not any measureable friction wear effects stated in the case of the friction couple of injection pump, in the form of reduction of a piston diameter of pumping section, in spite of usage of very accurate measuring methods with accuracy of $0.0002 \mathrm{~mm}$. During the research the systematic decrease of the tightness of the section was observed, due to the micro-cutting and fissuring with fuel pollution grains (Gil et al., 2010).

The problem can be occuring due to the microorganisms development in the fuelling systems, which can cause the row of processes influencing adversably on powering systems and the quality of the contained fuel. They include the filter clogging and fuel lines, injectors plugging, the corrosion of the tank or fuel lines, decomposition of hydrocarbons and refining additions, water and sulfur content increase in fuel, forming the sediments and solid particles suspension in fuel, and creating surface-active substances causing fuel emulsification (Lasocki and Karwowska, 2010). Thevegetable oil properties can be improved in the cold climate conditions via addition of ethanol, kerosene and commercial refiners (Bhale, 2009).

The research of the bio-fuel-powered engine emission gases points to the decrease of $\mathrm{CO}, \mathrm{HC}$ and solid particles emission and inrease of $\mathrm{NO}_{x}$ emission (Ulusoy et all, 2004). Positive effects were also obtained in the case of pure rapeseed oil powering the VW Golf 1.6D engine (Dzieniszewski and Piekarski, 2006).

Modern diesel engines solutions, besides the Common-Rail (C-R) fuel system, are equipped with many applications related to exhaust gas emmission cleaning. Beyond oxidating catalytic converter, there can often solid particle filters or SCR (Selective Catalytic Reduction) catalytic converters be met. Additionally, the EGR (exhaust gas recirculation) can work in system. By connecting bio-diesel and EGR it was tried to lower the $\mathrm{NO}_{x}$ and PM emission of the commercial truck working on low load. The combination of bio-diesel and EGR replaces the volatile state $\mathrm{O}_{2}$ from air with the oxygen in the fuel, what implies the $40 \%$ decrease of $\mathrm{PM}$ and $\mathrm{NO}_{\mathrm{x}}$ emmission comparing to using ultra-low diesel oil quantity with ultra-low sulfur content without recirculation. The $\mathrm{PM}$ decrease and proper $\mathrm{NO}_{x} / \mathrm{PM}$ ratio increase has a positive impact on DPF DPF (diesel particulate filter) operation, due to the more beneficial oxidation stoichiometry. Another advantage of this system is the possibility of $\mathrm{NO}_{x}$ reduction optimization via increasing the EGR quantity, during work in required DPF beneficial operation boundaries (Muncrief et al., 2008).

It is indicated that the more beneficial for the climate protec- tion and more energy effective is the usage of natural vegetable oil rather than FAME bio-diesel esters (Directive 2009/28/WE). Decentralized production and use of pure vegetable oil (PVO) as an independent fuel or bio-component can favor the rural areas development. In spite of that, most of the bio-fuel researche conducted in Europe and in Poland concerned the quality and utility parameters of FAME, what causes very one-sided and insufficient knowledge on the subject of organizational and technical possibilities of biofuel usage. Therefore, the urgent need of undertaking research of PVO fuelling and operating properties exists.

This paper is the first of the publication cycle related to the complex process, what is the production and using the vegetable oil in engine applications. As a beginning, the aim was stated to assess the viscosity and lubricity properties of the vegetable oil.

\section{FUELS AND RESEARCH PROCEDURES}

For the research, the refined rapeseed oil was used, compliant with PN-A-86908:2000 standard, and diesel oil, compliant with PN-EN 590:2006 standard, with fatty acid methyl esters containment not exceeding the $7 \%$ of fuel volume.

The viscosity and lubricity of pure diesel oil and pure vegetable oil was researched, as well as their mixtures with different proportions.

The viscosity is the fluid feature, which gives the information about the internal friction size, and mainly depends on temperature and pressure. The viscosity measure is so called viscosity indicator.

Researched liquid, in the amount of $50 \mathrm{ml}$, fills the space between spindle 2 and the measuring vessel 1 (Fig. 1). The viscometer operates on a method of measuring the friction force, with which the researched oil acts on the spinning spindle immersed in it. Basing on that force value and spindle with oil contact area, the tangent stresses are assessed. To enable viscosity research in different temperatures, the system was supplemented with temperature stablility system 3 with the thermal regulator. The technical data of the viscometer was showed in Tab. 2.

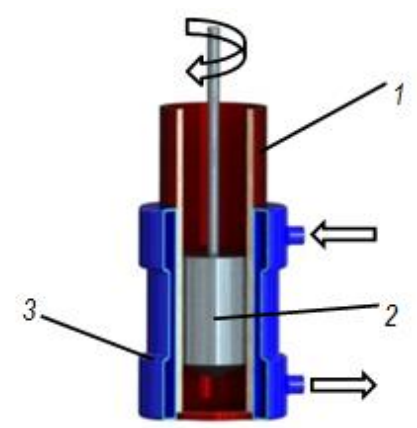

Fig. 1. The scheme showing the operation of viscometer DV-II+ Brookfield

Tab. 2. Technical data of the rotational viscometer DV-II+ Brookfield

\begin{tabular}{|l|l|}
\hline Parameter & Value \\
\hline - measurement range & $(1-6$ million $) \mathrm{mPa} \cdot \mathrm{s}$ \\
\hline - spindle rotational speed & $(0.01-200) \mathrm{rpm}$ \\
\hline - numbers of speeds & 54 \\
\hline - temperature range & $(0-99){ }^{\circ} \mathrm{C}$ \\
\hline - measured values & viscosity, shear stress, torque \\
\hline
\end{tabular}


The lubircity is the property, which states the capability of boundary layer creation on the solid mass surface. The value of the lubricity is the boundary layer durability, i.e. durability of connection between the lubricant with base. It can be, for example, assessed basing on the work amount, which must be applied to break the layer, or, what was used in research on the four-ball apparatus, basing on the phenomena related to the lubricity, i.e. wear processes, scuffing tendency.

The researching elements in four-ball apparatus are four bearing balls 1 made in 0th accuracy class and selection group tolerance of $0.8 \mu \mathrm{m}$ and Rockwell hardness of $60 \mathrm{HRC}$ (Fig. 2). The ball fixing in lower clamp 2 filled with researched lubricant with temperature of $20 \pm 5^{\circ} \mathrm{C}$ is realized by means of threaded shield with coned-shape hole 3 . Fixed balls (3 pieces) are tightened with variable force to the upper ball, which is rotated by electric motor, transmission and dedicated clamp. The technical data of the fourball apparatus is showed in Tab. 3 .

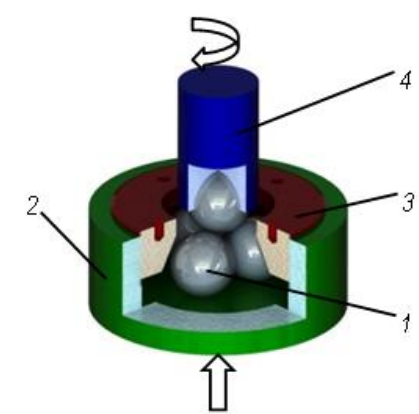

Fig. 2. The scheme illustrating the four-ball apparatus operation T-02

Tab. 3. Technical data of $\mathrm{T}-02$ apparatus

\begin{tabular}{|l|l|}
\hline Parameter & Value \\
\hline - sort of movement & turning \\
\hline - contact geometry & concentrated (3-point) \\
\hline - nominal ball diameter & $12.7 \mathrm{~mm}(0.5 \mathrm{in})$ \\
\hline - rotational speed & up to $1800 \mathrm{rpm}$ \\
\hline - load & up to $8000 \mathrm{~N}$ \\
\hline
\end{tabular}

The oil and lubricant boundary layer durability research consists of the measurement of the wear traces diameters, formed on the surfaces of three researched fixed balls for specific load values (tightening). The T-02 device enables the run of the research in order to the method described in PN-76/C-04147 standard.

The dynamic viscosity and lubricity research was realized by stage. Every time the research was repeated three times, and the results were averaged.

\section{RESEARCH RESULTS AND ANALYSIS}

The dynamic viscosity of the pure vegetable oil was increasing in low temperature (Fig. 3 ). In $5^{\circ} \mathrm{C}$ the vegetable oil is characterized with ca. 30 times difference related to the diesel oil. The $20 \%$ diesel oil addition decreases the differences by a half. Further diesel oil adding does not change the viscosity so significantly, as the first portion of 20 . None of the mixtures closens significantly to the diesel oil, in the boundary researched case $\left(80^{\circ} \mathrm{C}\right)$ the mixtures stay in the middle of the difference between vegetable and diesel oil.

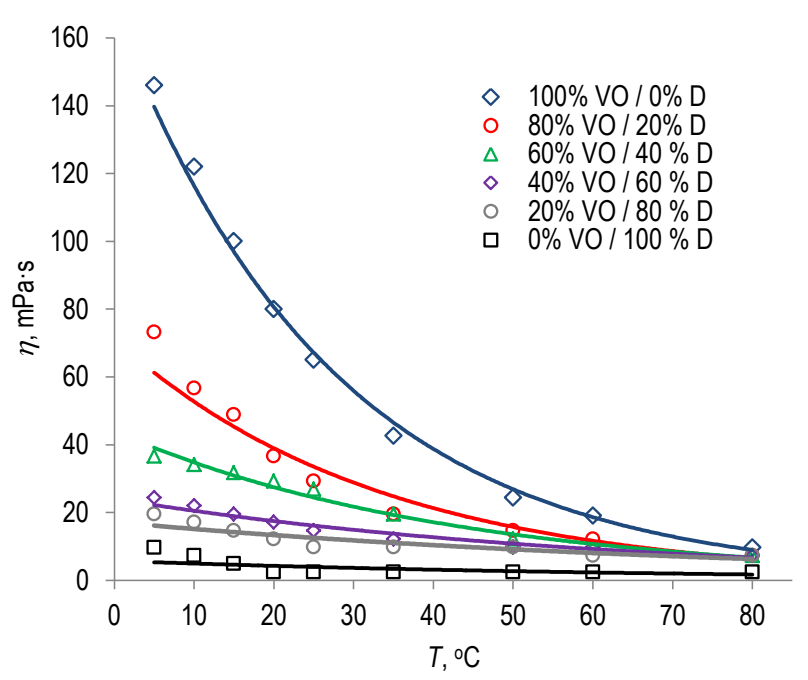

Fig. 3. Assessed values of dynamic viscosity: vegetable oil (VO), diesel (D)

The viscosity values of specific fuel mixture variants versus the temperature was approximated with expotential function, with using the non-linear regression, the method of least squares (Tab. 4).

Tab. 4. The approximation results of dynamic viscosity changes versus temperature

\begin{tabular}{|c|c|c|c|}
\hline No & ratio & $\begin{array}{c}\text { matching } \\
\text { function }\end{array}$ & $\begin{array}{c}\text { coefficient of } \\
\text { determination }\end{array}$ \\
\hline 1 & $100 \%$ VO / 0\% D & $y=167.84 \mathrm{e}^{-0.037 x}$ & $R^{2}=0.9956$ \\
\hline 2 & $80 \% \mathrm{VO} / 20 \% \mathrm{D}$ & $\mathrm{y}=71.263 \mathrm{e}^{-0.03 x}$ & $\mathrm{R}^{2}=0.9691$ \\
\hline 3 & $60 \% \mathrm{VO} / 40 \% \mathrm{D}$ & $\mathrm{y}=44.004 \mathrm{e}^{-0.024 x}$ & $\mathrm{R}^{2}=0.9835$ \\
\hline 4 & $40 \% \mathrm{VO} / 60 \% \mathrm{D}$ & $\mathrm{y}=24.043 \mathrm{e}^{-0.016 x}$ & $\mathrm{R}^{2}=0.9556$ \\
\hline 5 & $20 \% \mathrm{VO} / 80 \% \mathrm{D}$ & $\mathrm{y}=17.162 \mathrm{e}^{-0.013 x}$ & $\mathrm{R}^{2}=0.8215$ \\
\hline 6 & $0 \% \mathrm{VO} / 100 \% \mathrm{D}$ & $\mathrm{y}=5.7581 \mathrm{e}^{-0.015 x}$ & $\mathrm{R}^{2}=0.4753$ \\
\hline
\end{tabular}

The assessed viscosity values can be applicable in engine control systems. In the cases of temperature changes or the vegetable oil / diesel oil proportion change it can be selected via program method the redirection of the control module to the corresponding point on the map (Fig. 4).

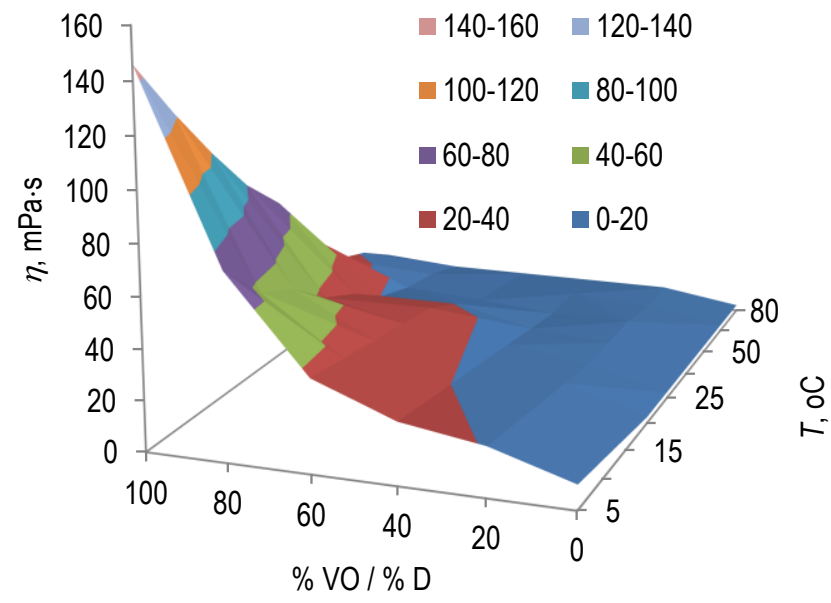

Fig. 4. Dynamic viscosity map: vegetable oil (VO), diesel (D) 
It was tried to approximate with the hypersurface the results showed in Fig. 4 by using the multiple regression. Unfortunately, the function elaborated in such way is not capable of describing the whole, the boundary values do not match. Thus proposed the triangulation from result matrix to the calculation algorithms, where designated triangle suspended in space would let approximately designate the dynamic viscosity value and as an effect, application of coefficient value correcting powering system parameters.

The research showed, that dynamic viscosity values of pure vegetable oil and researched mixture with various percentage of diesel oil exceed the standard of the pure diesel oil stated by calculating relatively to the density $(3.4-3.7) \mathrm{mPa} \cdot \mathrm{s}$ in $40^{\circ} \mathrm{C}$ (Baczewki and Kałdoński, 2004). Thus the necessity of fuelling system modification occurs: bigger flow sections and fuel heating. The authors are during the elaboration of original correction of the engine control system offsetting the viscosity differences, what they are planning to show in following papers.

High viscosity values in the case of pure vegetable oil show the necessity of fuel heating in the preliminary phase of pumping in the fuelling system. Modified to power with pure vegetable oil engine control systems of presented agricultural tractors (2ndWegOil, Pasyniuk and Golimowski, 2011) besides the fuel heating system, were equipped with engine cooling system heating systems for the quickest possible nominal temperature reaching. Increased viscosity also causes problems with fuel pumping in the high pressure pump (in the case of Common-Rail), or in the injecting pump, not mentioning the injectors themselves. The vegetable oil, during flowing through the injector, especially of a new power unit with $\mathrm{C}-\mathrm{R}$ system with outlet nozzles of $0.012 \mathrm{~mm}$ of diameter, can cause irregular dosage, what is also a research topic for authors.

The very significant feature is a lubricity of researched fuels and their mixtures in various mixing rates. As previously mentioned, injecting pump measurement operated on the vegetable oil did not show the significant wear traces (Gil et al., 2010), besides the tightness loss. Therefore attempted to check the lubricity parameter, in conditions significantly exceeding loads resulting from friction couples cooperation in fuelling system.

The flaws formed on the measuring balls were averaged. The flaws of the size up to $1.5 \mathrm{~mm}$ were measured with Olimpus BX 51 microscope with a magnification of $(25-1000) x$, over that value - with a magnifying Brinell glass with a magnification of $20 x$, with the accuracy of $0.01 \mathrm{~mm}$. In Fig. 5 the sample visualization of the flaw was showed, designated with Olimpus BX 51 microscope.

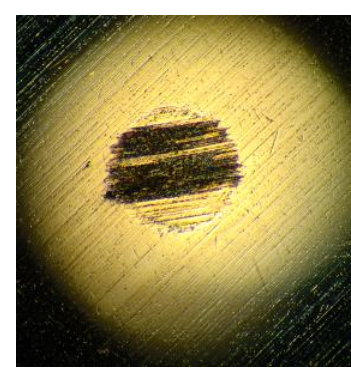

Fig. 5. Sample visualization of the flaw designated with Olimpus BX 51 microscope

As a result of lubricity attempts on four-ball apparatus, noted that the lubricant in the form of pure diesel oil causes seizure of balls with lower load, than it is in the case of mixtures and pure vegetable oil. (Fig. 6, Tab. 5).
Whereas in the case of the viscosity even insignificant diesel oil amounts caused significant decrease of mixture viscosity, in the case of lubricity - even small addition of vegetable oil to the diesel oil significantly improves the lubricity of the mixture.

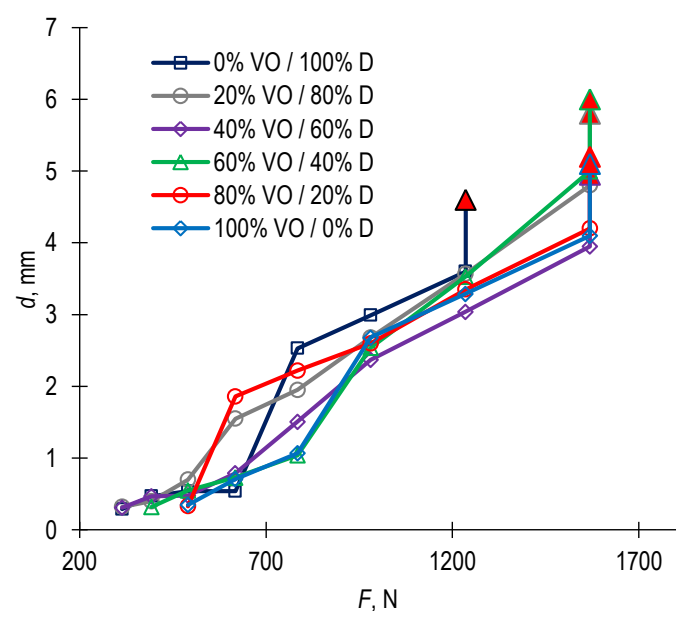

Fig. 6. Lubricity research results- flaws diameters versus load

Tab. 5. Lubricity research resutls

\begin{tabular}{|c|c|c|c|}
\hline No & ratio & $\begin{array}{c}\text { max. load } \\
\text { N }\end{array}$ & $\begin{array}{c}\text { scar diameters } \\
\text { mm }\end{array}$ \\
\hline 1 & $100 \% \mathrm{VO} / 0 \% \mathrm{D}$ & 1569 & 5.1 \\
\hline 2 & $80 \% \mathrm{VO} / 20 \% \mathrm{D}$ & 1569 & 5.2 \\
\hline 3 & $60 \% \mathrm{VO} / 40 \% \mathrm{D}$ & 1569 & 6.0 \\
\hline 4 & $40 \% \mathrm{VO} / 60 \% \mathrm{D}$ & 1569 & 4.9 \\
\hline 5 & $20 \% \mathrm{VO} / 80 \% \mathrm{D}$ & 1569 & 5.8 \\
\hline 6 & $0 \% \mathrm{VO} / 100 \% \mathrm{D}$ & 1236 & 4.6 \\
\hline
\end{tabular}

Marking the lubricity via measurement of the flaws diameter indicates that the engine powered with pure vegetable oil should not wear more excessively in time in the friction nodes, than the engine powered with the diesel engine. The dominant question is obviously vegetable oil pureness (Gil et al., 2010).

\section{SUMMARY}

Basing on the conducted research it can be stated that:

1. Pure vegetable (rapeseed) oil in the lowest of researched tempereatures showed 30 times more dynamic viscosity than the diesel oil.

2. Even small addition of the diesel oil $(20 \%)$ to the vegetable oil lowered the dynamic viscosity by $20 \%$.

3. For engine applications, it is necessary to heat the vegetable oil in the pumping process in the fuelling system for reaching the required viscosity. In replacement, flow sections can be increased, as far as possible, in constriction places (injector nozzles).

4. The researched vegetable oil lubricity exceeds the diesel oil lubricity, thus it should not be the cause of extensive wear or tightening loss of the fuel pumping systems.

5. Mixing the vegetable oil with the diesel oil does not change the lubricity in significant way. 


\section{REFERENCES}

1. 2ndWegOil project 7 , The Framework Programme No TREN/FP7/ 219004.

2. A policy framework for climate and energy in the period from 2020 to 2030, Communication from the Commission to the European Parliament, The Council, The European Economic and Social Committee and the Committee of the Regions, 2014.

3. Abschlussbericht (2005), Praxiseinsatz von serienmäßigen neuen rapsöltauglichen Traktoren“, Universität Rostock, Aktenzeichen, 00 NR 200.

4. Amarnath H. K., Prabhakaran P., Sachin A., Bhat A., Paatil R. (2012), A comparative experimental study between the biodiesel of karanja, jatropha and palm oils based on their performance and emsission in a four storke diesel engine, ARPN Journal of Engineering and Applied Sciences, 7, 407-414.

5. Baczewski K., Kałdoński T. (2004), Fuel for diesel engines, WKiL, Warsaw.

6. Bhale P. V., Deshpande N. V. (2009), Thombre, S.B. Improving the low temperature properties of biodiesel fuel, Renew. Energy 2009, $34,794-800$.

7. Bocheński C. I., Bocheńska A. M. (2005), Testing properties of engine oil mix with rape oil methyl esters, MOTROL - Motorization and Power Industry in Agriculture, Vol. 7, 24-34.

8. Bocheński C. I., Warsicki K., Bocheńska A. M. (2005), Comparison of process of stream creation and diesel oil and rape oil esters combustion in the research combustion chamber at single and diphause fuel injection, Journal of KONES Internal Combustion Engines, Vol. 12(3-4), 33-42.

9. Canakci M. (2007), Combustion characteristics of a turbocharged DI compression ignition engine fueled with petroleum diesel fuels and biodiesel, Bioresour. Technol., 98, 1167-1175.

10. Cisek J., Mruk A. (2012), Characteristics of a diesel engine fuelled by natural rape oil, Proceedings of the Institute of Vehicle, Faculty of Automotive and Constuction Machinery Engineering, Warsaw University of Technology, Vol. 1(87), 5-16.

11. Commission Directive 2010/26 / EU of 31 March 2010. Amending Directive $97 / 68$ / EC of the European Parliament and of the Council on the approximation of the laws of Member States relating to measures against the emission of gaseous and particulate pollutants from internal combustion engines to be installed in non-mobile machinery on the road.

12. Directive of the European Parliament and of the Council 2009/28 / EC of 23 April 2009. In the promotion of energy from renewable sources and amending and subsequently repealing Directives 2001/77 / EC and 2003/30 / EC.

13. Durbin T. D., Collins J. R., Norbeck J. M., Smith, M. R. (200), Effects of biodiesel, biodiesel blends, and a synthetic diesel on emissions from light heavy-duty diesel vehicles,Environ. Sci. Technol., 34, 349-355.

14. Dzieniszewski G., Piekarski W. (2006), The select problems of feeding diesel engines with low-processed rape oil, Eksploatacja I Niezawodność, Vol. 3, 58-65.

15. Emberger P., Thuneke K., Remmele E. (2012), The pure vegetable oil suitable tractors of the stage IIIA. Results of test runs and field operation conducted on premises of the Bavarian State Research Center for Agriculture, (in German). Berichte aus dem TFZ, 32, Straubing.

16. Gil L., Ignaciuk P., Niewczas A. (2010), Investigation of wear of injection system components in diesel engine fueled with vegetable fuels, Journal of Science of the Gen. Tadeusz Kosciuszko Military Academy of Land Forces, Vol. 4(158), 100-108.

17. HLPE (2013), Biofuels and food security. A report by the High Level Panel of Experts on Food Security and Nutrition of the Committee on World Food Security, Rome.

18. Kaplan C., Arslan R., Surmen A. (2006), Performance characteristics of sunflower methyl esters as biodiesel, Energy Sources Part A Recovery Util. Environ. Eff., 28, 751-755.
19. Karavalakis G., Stournas S., Bakeas E. (2009), Light vehicle regulated and unregulated emissions from different biodiesels, Sci. Total Environ., 407, 3338-3346.

20. Łaska B., Wawrzyniak A., Szulc R., Golimowski W., Pasyniuk P. (2013), Comparsion of physical and chemical properties of crude coldpressed vegetable oils used to drive agricultural tractors, Journal of Research and Applications in Agricultural Engineering, Vol. 58(2), 116-118.

21. Lasocki J., Karwowska E. (2010), The influence of microorganisms present in diesel and biodiesel on the fuel systems of vehicles equipped with diesel engines, The Archives of Automotive Engineering - Archiwum Motoryzacji, Vol. 3, 167-183.

22. Lin B. F., Huang J. H., Huang D. Y. (2009), Experimental study of the effects of vegetable oil methyl ester on $\mathrm{DI}$ diesel engine performance characteristics and pollutant emissions, Fuel, 88, 1779-1785.

23. Lin Y., Wu Y. G., Chang C. (2007), Combustion characteristics of waste-oil produced biodiesel/diesel fuel blends, Fuel, 86, 2810-2816.

24. Monyem A., Van Gerpen J. H. (2001), The effect of biodiesel oxidation on engine performance and emissions, Biomass Bioenergy, 20, 317-325.

25. Muncrief R. L., Rooks C. W., Cruz M., Michael P. H. (2008) Combining biodiesel and exhaust gas recirculation for reduction in NOx and particulate emissions, Energy Fuels, 22, 1285-1296.

26. Nabi M. N., Akhter M. S., Zaglul Shahadat M. M. (2006) Improvement of engine emissions with conventional diesel fuel and diesel-biodiesel blends, Bioresour. Technol., 97, 372-378.

27. Opinion of the European Economic and Social Committee on the Proposal for a Directive of the European Parliament and of the Council amending Directive $98 / 70$ / EC relating to the quality of petrol and diesel fuels and amending Directive 2009/28 / EC on the promotion of energy from renewable sources COM (2012) 595 final 2012/0288 (COD).

28. Pasyniuk P., Golimowski W. (2011), Effect of rapeseed oil on the parameters of a diesel engine of John Deere tractor, model 6830 , Journal of Research and Applications in Agricultural Engineering, Vol. 56(2), 118-121.

29. Raheman H., Phadatare A. G. (2004), Diesel engine emissions and performance from blends of karanja methyl ester and diesel, Biomass Bioenergy, 27, 393-397.

30. Szlachta Z., Dudek S. (2003), The biofueling agricultural vehicle engines, MOTROL - Motorization and Power Industry in Agriculture, vol. 5, 192-200.

31. Tesfa B., Gu F., Mishra R., Ball A. (2014), Emission Characteristics of a $\mathrm{Cl}$ Engine Running with a Range of Biodiesel Feedstocks, Energies, 7, 334-350.

32. Ulusoy Y., Tekin Y., Cetinkaya M., Karaosmanoglu F. (2004), The engine tests of biodiesel from used frying oil, Energy Sources, 26, 927-932.

33. Wasilewski J. (2006), Comparative assessment of fuel consumption by tractor engine fed with rapeseed biofuel and diesel fuel, Inżynieria Rolnicza, Vol. 6, 349-355.

34. Wcisło G. (2008), Determination of temperature impact on dynamic viscosity of plant biofuels, Inżynieria Rolnicza, Vol. 10(108), 277-282.

The investigations described in this paper are a part of the research project WND-RPPD.01.01.00-20-015/12 Fri. Examination of the effectiveness of active and passive methods to improve energy efficiency infrastructure using renewable energy sources Priority Axis I. Increased innovation and supporting entrepreneurship in the region, Measure 1.1. Creating conditions for the development of innovation, co-financed by the European Regional Development Fund and the state budget under the Regional Operational Programme 2007-2013 Podlaski "TO120362/106/14 realized at Bialystok University of Technology. 